\title{
Selected Varieties of Dioscorea esculenta, a Yam for the Hot, Humid Tropics ${ }^{1}$
}

\author{
Franklin W. Martin and Herminio Delpin ${ }^{2}$
}

\begin{abstract}
Eighty five cultivars of Dioscorea esculenta were evaluated with respect to 54 morphological, physiological, agronomic, and culinary characteristics. Six superior varieties were selected and described. These are high yielding, disease and insect resistant, and excellent in the kitchen and at the table. These varieties should prove useful in Puerto Rico and other parts of the Caribbean, especially in substitution for the imported potato.
\end{abstract}

\section{INTRODUCTION}

The cultivars of the edible species of yam have been spread throughout the tropics and subtropics in a rather haphazard fashion. The types in use in any particular region are often those introduced by chance and seldom have they been selected for desirable qualities. Of the 10 or more cultivated species, one little known, Dioscorea esculenta (Lour.) Burk. is of great potential. This species may have originated on the Malay Peninsula, but exhibits a center of variation in Papua New Guinea ${ }^{3}$. The range of variation of this and other yam species found in this region has never been completely described. The well known small-tubered cultivars found in West Africa and the American tropics are thought to be rare introductions from Southeast Asia.

Recent collections of cultivars from Southeast Asia to the islands of the Pacific Ocean ${ }^{4}$ have made possible an advance in knowledge of this species. From the collections, selections of superior varieties were made. These need trial throughout the yam production areas of the tropics for their potential in comparison with other yam species.

\section{MATERIALS AND METHODS}

The selected cultivars of Dioscorea esculenta described here were among 85 obtained from various parts of Southeast Asia and Islands of the Pacific. The collection also included varieties introduced to West

' Manuscript submitted to Editorial Board July 6, 1977.

${ }^{2}$ Horticulturist and Agricultural Research Technician, Mayagüez Institute of Tropical Agriculture, Agricultural Research Service, U.S. Department of Agriculture, Mayagüez, P.R.

${ }^{3}$ Coursey, D. G., Yams. An account of the nature, origins, cultivation, and utilization of the useful members of the Dioscoreaceae, Longmans, London 230 pp.

${ }^{4}$ Martin, F. W., Tropical yams and their potential, Part 1. Dioscorea esculenta, Agricultural Handbook No. 457, Agricultural Research Service, U.S. Department of Agriculture, 18 pp., 1974. 
Africa and the Caribbean. Characteristics of these were noted that were beyond the ranges of characteristics of previously described cultivars.

The cultivars were planted from tuber pieces or small tubers in a heavy clay soil in Mayagüez, Puerto Rico. About 25 tons/ha partially rotted cachaza (sugarcane filter press cake) was incorporated into the soil with a rototiller, and ridges of $.75 \mathrm{~m}$ in width and $.35 \mathrm{~m}$ high were formed. Planting ridges were $1.5 \mathrm{~m}$ apart, and plants were spaced $0.6 \mathrm{~m}$ apart on the ridges. Plants were staked with bamboo poles $2 \mathrm{~m}$ in height. After germination of the tubers, 10-5-15 commercial fertilizer was placed in a small circle around the plants at the rate of $800 \mathrm{~kg} / \mathrm{ha}$. The plants were not treated in any way for insects or diseases, but weeds were controlled manually for the first 3 mo of field growth. Plantings were made at the beginning of the rainy season in Puerto Rico and harvested about $10 \mathrm{mo}$ later, when the foliage withered during the dry season. The tubers were then dug with shovels and spading forks.

Complete notes were made of characteristics of the leaf, stem, and tuber, and of certain physiological characteristics. The culinary characteristics were observed in the laboratory before and after cooking. All 54 characteristics rated are given in table 1 , for they constitute a model of the appropriate evaluation for this species. Field trials were continued over 3 years, accompanied by preliminary and final selections for yield, agronomic, and culinary characteristics. Yields of the six final selections were evaluated in completely randomized blocks of five replications.

\section{RESULTS}

\section{VARIATION SEEN IN THE COLLECTION}

Stems were often tinged with small amounts of anthocyanin; they ranged from slightly to very pubescent, and slightly to very thorny. Mature leaves varied from 60 to $167 \mathrm{~mm}$ in length and from 65 to 164 $\mathrm{mm}$ in width, often roundish, or wider than long, sometimes with a short tail, often shiny or rugose, and sometimes showing virus symptoms. Varietal differences were not pronounced with respect to foliar characteristics (fig. 1), but with practice varieties could be distinguished.

The tubers were extremely varied, and useful in distinguishing varieties. Tubers were often borne in compact clusters but, in other cases stolons up to a $35 \mathrm{~cm}$ long were measured. Long stolons make harvest difficult. Tubers varied in number per plant from one to perhaps hundreds. As tuber number increased, tuber size decreased. Single tubers as large as 5 kg were produced (fig. 2), often as spheres or short cylinders. Although branching was not common, it did occur, and tuber shapes were then very irregular. Tubers were almost always longer than wide.

The cortex of the tuber was often pink due to the presence of anthocyanin, and the flesh was occasionally light-yellow or mottled purple. In 
TABLE 1.-Measured or rated characteristics of Dioscorea esculenta cultivars

\begin{tabular}{|c|c|c|c|c|}
\hline $\begin{array}{l}\text { Type of } \\
\text { charac- } \\
\text { teristics }\end{array}$ & $\begin{array}{l}\text { Charac- } \\
\text { teristic } \\
\text { number }\end{array}$ & Characteristic & $\begin{array}{c}\text { Measured } \\
\text { (M), } \\
\text { rate } \\
\text { (R), or } \\
\text { estimated } \\
\text { (E) }\end{array}$ & $\begin{array}{l}\text { Measurement } \\
\text { or scale }\end{array}$ \\
\hline \multirow[t]{4}{*}{ Stem } & 1 & Vigor & $\mathrm{R}$ & $1-5$ \\
\hline & 2 & Anthocyanin content & $\mathrm{R}$ & $0-5$ \\
\hline & 3 & Pubescence & $\mathrm{R}$ & $0-5$ \\
\hline & 4 & Thorniness & $\mathrm{R}$ & $0-5$ \\
\hline \multirow[t]{13}{*}{ Leaf } & 5 & Length & M & $\mathrm{Cm}$ \\
\hline & 6 & Width & M & $\mathrm{Cm}$ \\
\hline & 7 & Area & $\mathrm{R}$ & $1-5$ \\
\hline & 8 & Roundness & $\mathrm{R}$ & $1-5$ \\
\hline & 9 & Presence of tail & $\mathrm{R}$ & $1-5$ \\
\hline & 10 & Size of sinus & $\mathrm{E}$ & $1-5$ \\
\hline & 11 & Rugosity & $\mathrm{R}$ & $1-5$ \\
\hline & 12 & Shine & $\mathrm{R}$ & $1-5$ \\
\hline & 13 & Leaf spot disease & $\mathrm{R}$ & $0-5$ \\
\hline & 14 & Virus disease & $\mathrm{R}$ & $0-5$ \\
\hline & 15 & Anthocyanin content & $\mathrm{R}$ & $0-5$ \\
\hline & 16 & Flowering & $\mathrm{R}$ & $\begin{array}{l}0=\text { no flowers seen, } \\
1 \text { flowers seen }\end{array}$ \\
\hline & 17 & Sex & $\mathrm{R}$ & $1=$ female, $2=$ male \\
\hline \multirow[t]{16}{*}{ Tuber } & 18 & Stolon length & M & $\mathrm{Cm}$ \\
\hline & 19 & Tendency to fork & $\mathrm{R}$ & $0-3$ \\
\hline & 20 & Place of branching & $\mathrm{R}$ & $\begin{array}{c}0-5 \text { (1=near head, } \\
5=\text { near tip) }\end{array}$ \\
\hline & 21 & Irregularity of shape & $\mathrm{R}$ & $1-3$ \\
\hline & 22 & Length of tuber & M & $\mathrm{Cm}$ \\
\hline & 23 & Diameter of tuber & M & $\mathrm{Cm}$ \\
\hline & 24 & Diameter/length & M & As ratio \\
\hline & 25 & Durability of cortex & $\mathrm{R}$ & $1-3$ \\
\hline & 26 & Thickness of cortex & $\mathrm{R}$ & $1-3$ \\
\hline & 27 & Presence of roots & $\mathrm{R}$ & $0-3$ \\
\hline & 28 & Presence of thorns & R & $0-3$ \\
\hline & 29 & $\begin{array}{l}\text { Uniformity of cross sec- } \\
\text { tion }\end{array}$ & $\mathrm{R}$ & $1-3$ \\
\hline & 30 & Oxidation tendency & $\mathrm{R}$ & $0-3$ \\
\hline & 31 & Gums released & $\mathrm{R}$ & $1-3$ \\
\hline & 32 & Insect damage & $\mathrm{R}$ & $0-3$ \\
\hline & 33 & $\begin{array}{l}\text { Desirability, based on } \\
\text { tuber characteristics }\end{array}$ & $\mathrm{R}$ & $\begin{array}{l}\text { 1-5 ( } 5=\text { highly desira }- \\
\text { ble) }\end{array}$ \\
\hline \multirow[t]{6}{*}{ Culinary } & 34 & Ease of peeling & $\mathrm{R}$ & $1-3$ \\
\hline & 35 & Sting of flesh & $\mathrm{R}$ & $0-2$ \\
\hline & 36 & Grainy appearance & $R$ & $1-3$ \\
\hline & 37 & Cooking time & M & Minutes \\
\hline & 38 & $\begin{array}{l}\text { Dirtiness of cooking } \\
\text { water }\end{array}$ & $\mathrm{R}$ & $1-3$ \\
\hline & 39 & $\begin{array}{l}\text { Appearance when } \\
\text { cooked }\end{array}$ & $\mathrm{R}$ & $\begin{array}{l}\text { 1-3 ( } 3=\text { highly attrac- } \\
\text { tive) }\end{array}$ \\
\hline
\end{tabular}


TABLE 1 continued

\begin{tabular}{|c|c|c|c|c|}
\hline $\begin{array}{l}\text { Type of } \\
\text { charac- } \\
\text { teristics }\end{array}$ & $\begin{array}{l}\text { Charac- } \\
\text { teristic } \\
\text { number }\end{array}$ & Characteristic & $\begin{array}{l}\text { Measured } \\
(\mathrm{M}), \\
\text { rate } \\
(\mathrm{R}) \text {, or } \\
\text { estimated } \\
\text { (E) }\end{array}$ & $\begin{array}{l}\text { Measurement } \\
\text { or scale }\end{array}$ \\
\hline & 40 & Color & $\mathrm{R}$ & $\begin{array}{l}\text { 1-5 (white, light cream, } \\
\text { cream, yellow, pur- } \\
\text { ple) }\end{array}$ \\
\hline & 41 & Erosion on cooking & $\mathrm{R}$ & $0-3$ \\
\hline \multirow[t]{8}{*}{ Table } & 42 & Stickiness & $\mathbf{R}$ & $1-3$ \\
\hline & 43 & Texture, fine to coarse & $\mathrm{R}$ & $1-3$ \\
\hline & 44 & Flavor & $\mathbf{R}$ & $1-3$ \\
\hline & 45 & Sweetness & $\mathrm{R}$ & $0-3$ \\
\hline & 46 & Moisture & $\mathrm{R}$ & $1-3$ \\
\hline & 47 & Bitterness & $\mathrm{R}$ & $0-3$ \\
\hline & 48 & Fiber & $\mathrm{R}$ & $0-3$ \\
\hline & 49 & $\begin{array}{l}\text { Estimated value as } \\
\text { cooked vegetable }\end{array}$ & $\mathrm{R}$ & I-3 $(3=$ most valuable $)$ \\
\hline \multirow[t]{5}{*}{ Others } & 50 & Dry weight & M & As $\%$ \\
\hline & 51 & Starch content & M & As $\%$ \\
\hline & 52 & Amylose content & M & As $\%$ \\
\hline & 53 & $\begin{array}{l}\text { Germination after } \\
\text { planting }\end{array}$ & M & As $\%$ \\
\hline & 54 & Virus symptoms & - & Described, and noted \\
\hline
\end{tabular}

most varieties the flesh was uniformly white and finely textured to slightly grainy. As a rule, the flesh of large and colored tubers tended to discolor when cut, due to polyphenolic oxidation, and was poor in appearance after cooking.

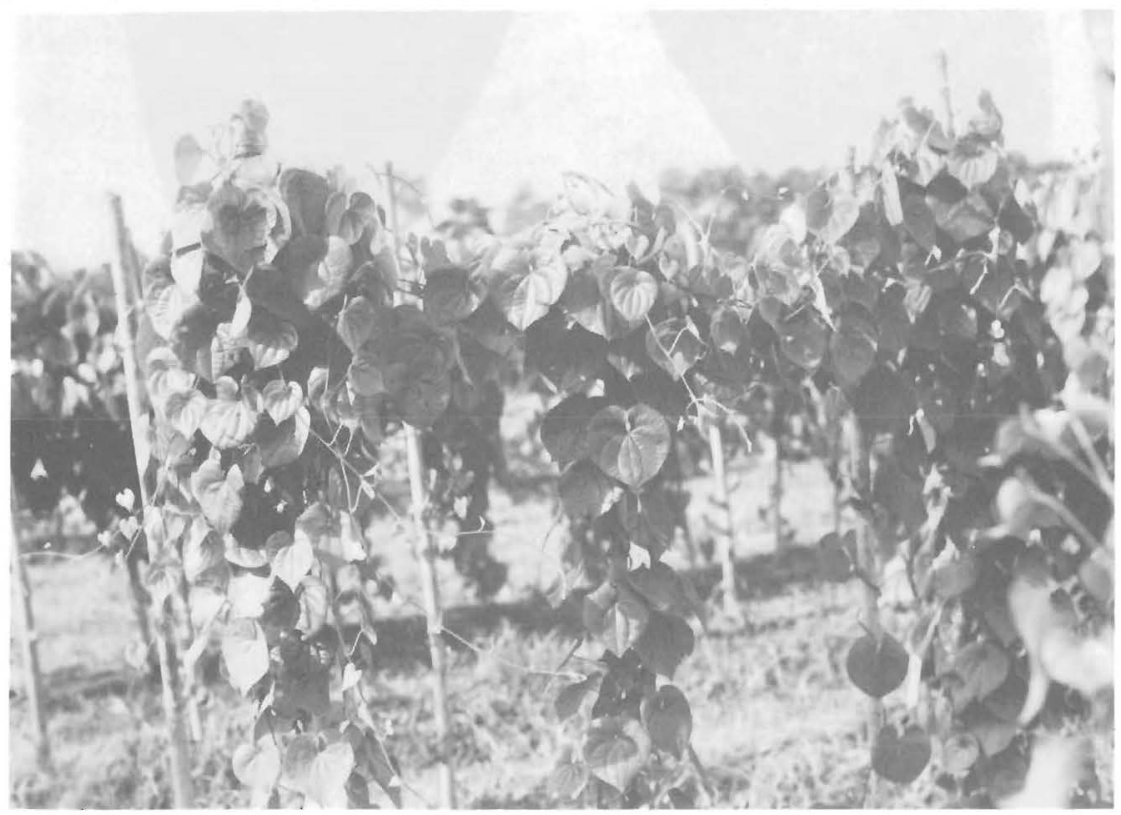

Fig. 1.-Typical foliage of Dioscorea esculenta. 


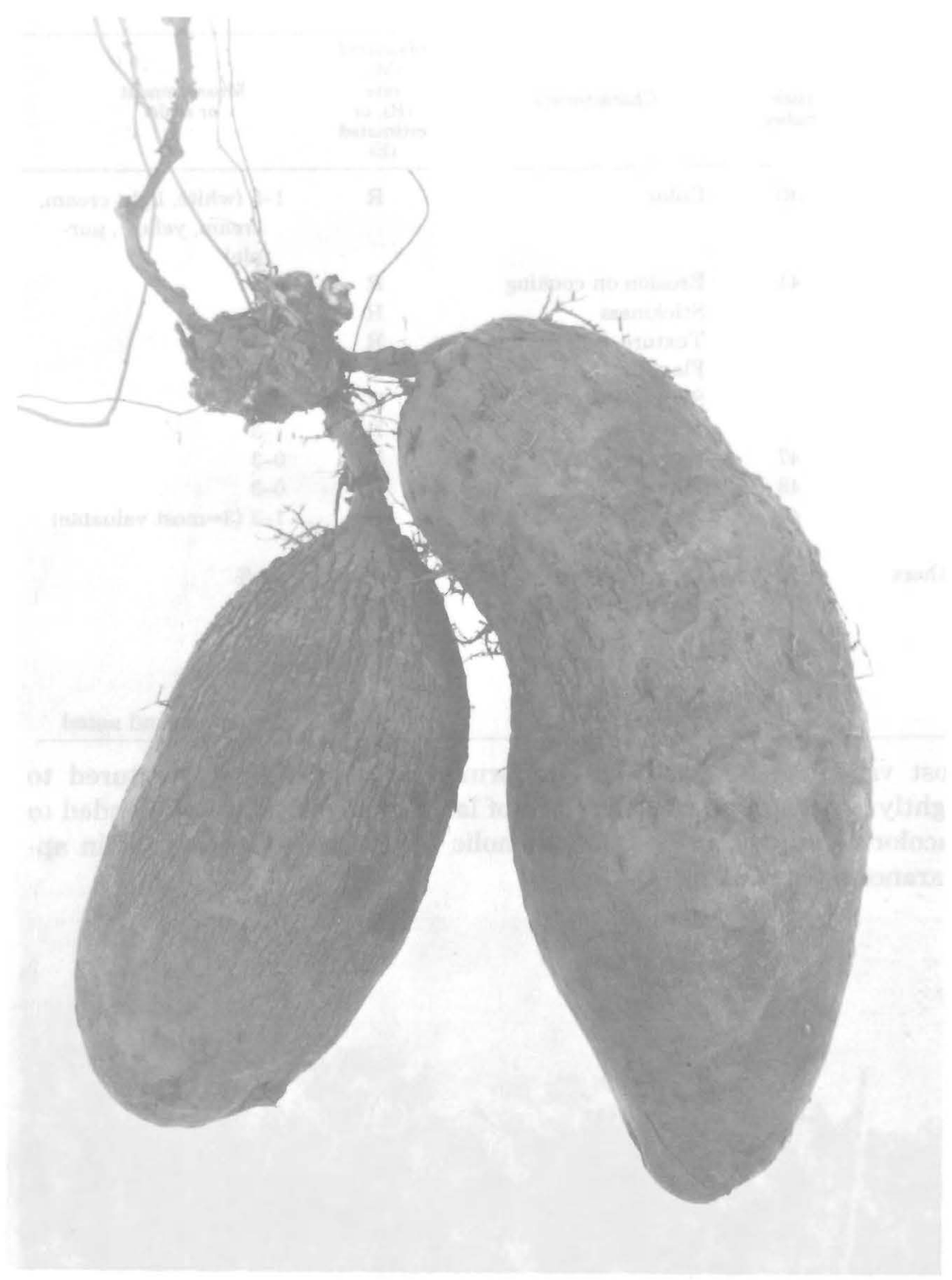

FIg. 2.-Large tubers of $D$. esculenta of about 2 and $3 \mathrm{~kg}$, respectively.

Tubers were sometimes soft and eroded when cooked. Others were crispy even after cooking. Most were sweet and moist, but these characteristics varied. Some of the larger tubers and a few of the smaller were acrid or bitter in taste, but taste of most was rich and appealing. The 


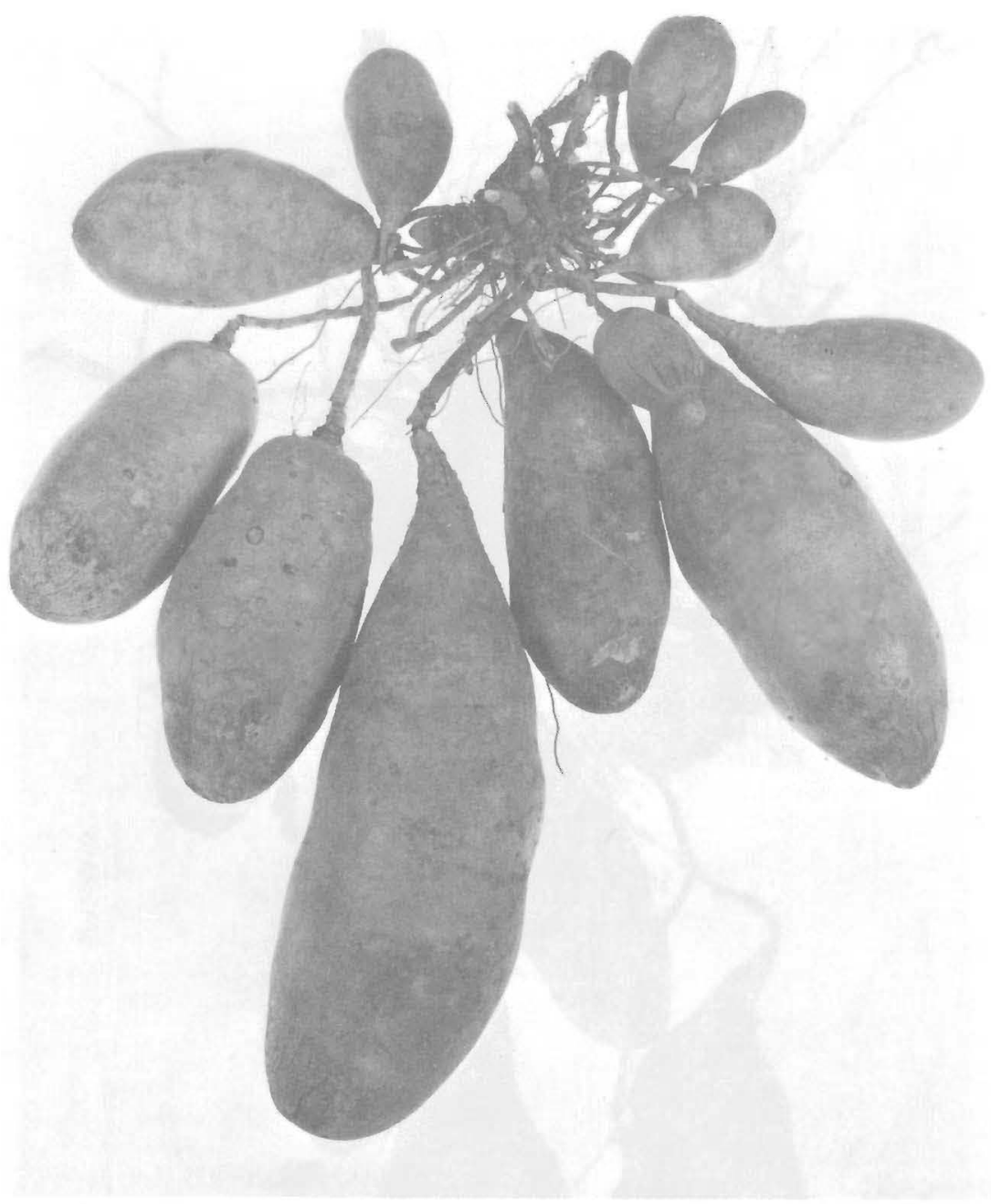

Fig. 3.-The very smooth tubers of variety Beti.

cooked flesh was usually smooth in texture, but sometimes contained fibers or was sticky.

The dry weight of tubers varied from 21 to $40 \%$, and starch content from 16 to $27 \%$. The amylose content of the starch varied from 7 to $24 \%$.

\section{DESCRIPTIONS OF SELECTED VARIETIES}

Beti (fig. 3)

Fair germination, vigorous anthocyanin-tinged vines of average thor- 


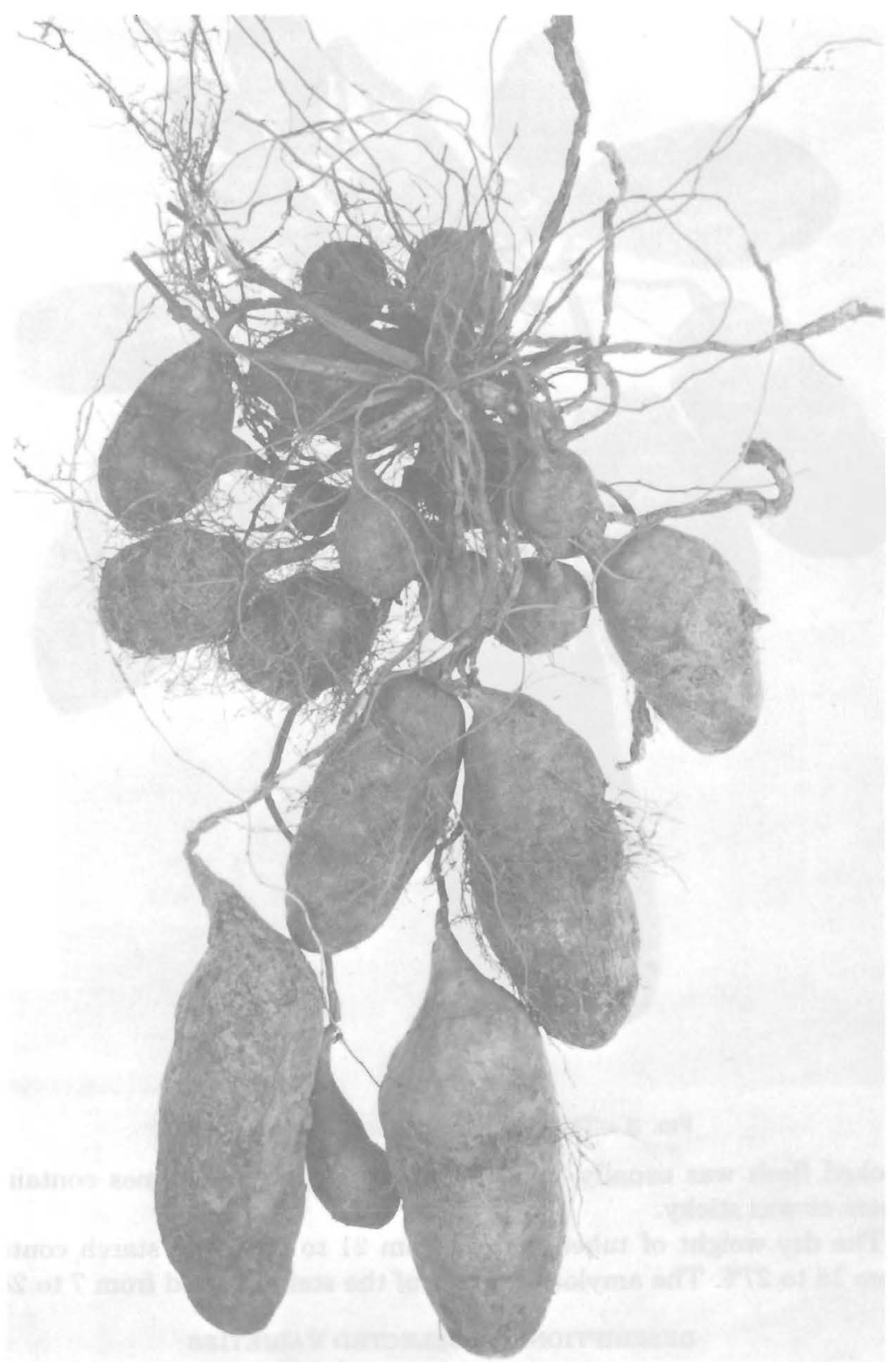

FIG. 4.-Tubers of variety Doli. 
niness, rugose leaves wider than long, seldom any sign of virus. Crown almost free of spines, clusters small and compact, tuber size variable, but many large, up to $1 \mathrm{~kg}$, ellipsoidal to spindle shaped, free of surface roots, very smooth, epidermis tough. Yields low to medium. Flesh light cream, uniform, does not sting. Excellent cooking characteristics: sweet, moist, with smooth texture, somewhat sticky. High dry weight, medium starch content, and low amylose content. Received as Kuan, from Bo, Namatanai, Papua New Guinea. Considered the best cultivar seen.

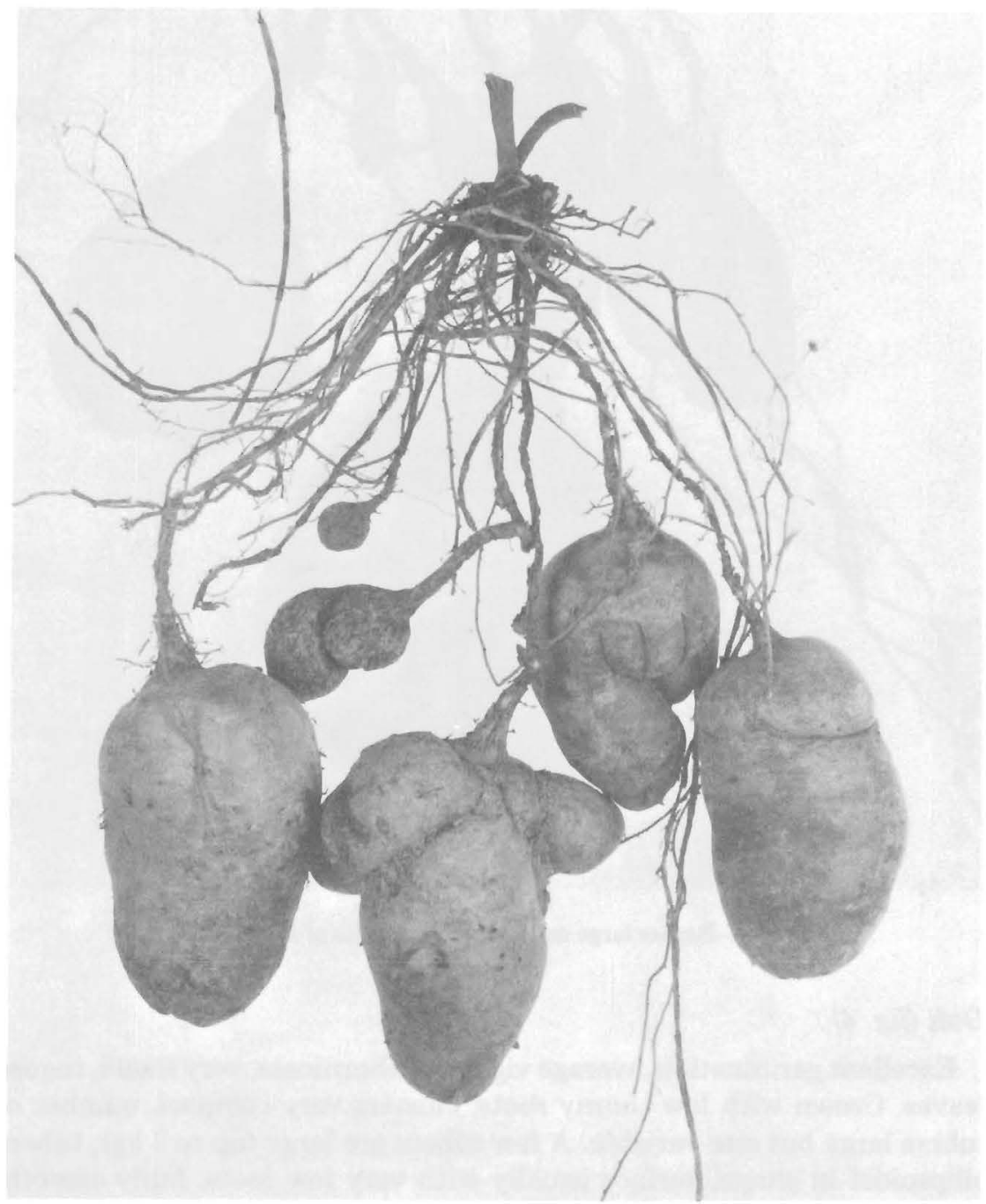

Frg. 5.-Tubers of variety Muni. 


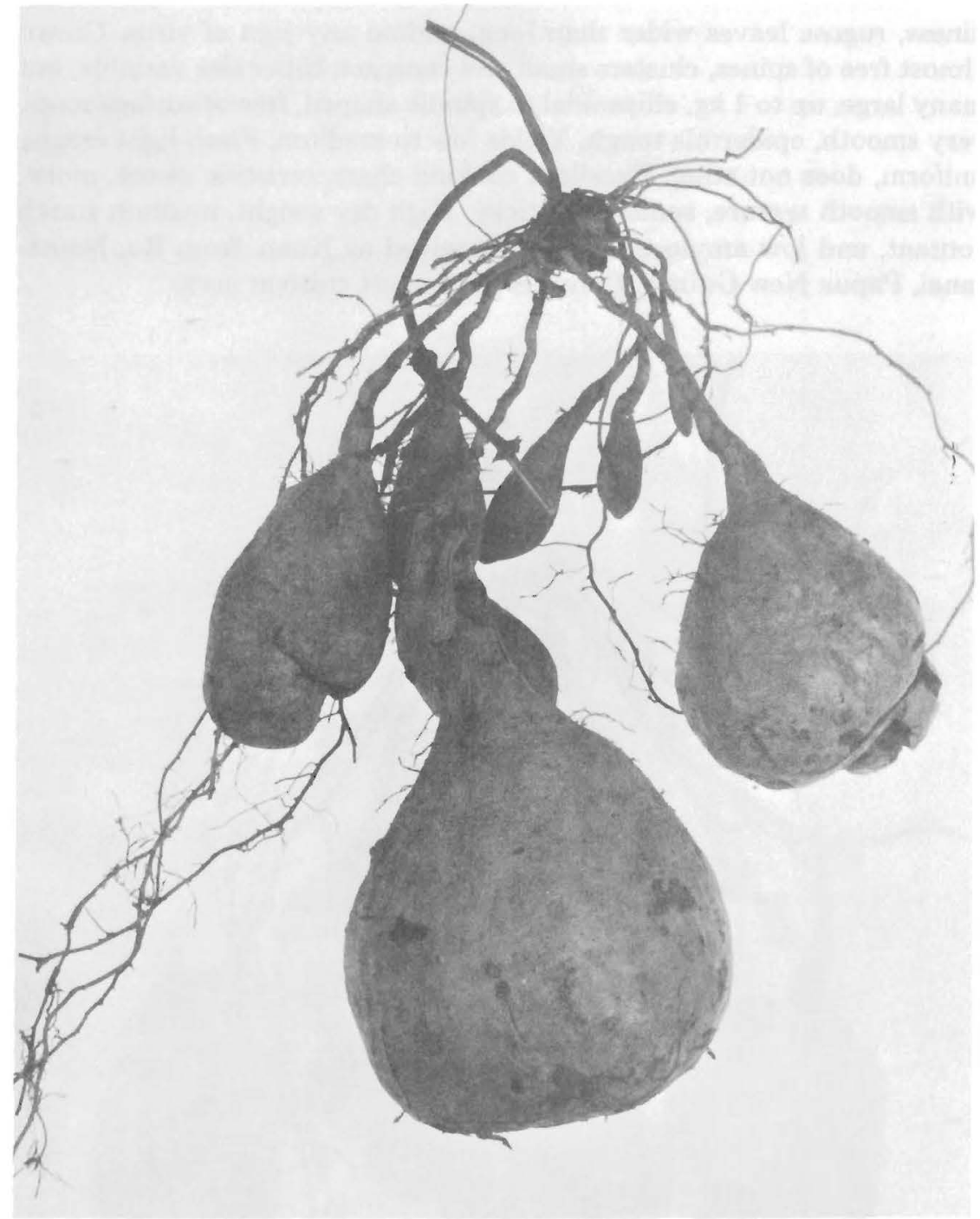

FIG. 6.-Rather large and pyramidal tubers of variety Viola.

\section{Doli (fig. 4)}

Excellent germination, average vigor and thorniness, very round, rugose leaves. Crown with few thorny roots, clusters very compact, number of tubers large but size variable. A few tubers are large (up to $1 \mathrm{~kg}$ ), tubers ellipsoidal in shape, surface usually with very few roots, fairly smooth, epidermis thin, yields medium. Flesh creamy in color, uniform, does not 
sting. Cooking characteristics: very good, sweet, very moist, smooth texture, and little stickiness. Low dry weight, medium starch content (21\%) and somewhat low amylose content (13.5\%). Received as Samo, from Bo, Namatanai, Papua New Guinea.

Muni (fig. 5)

Good germination, vigorous, pubescent vines of average thorniness,

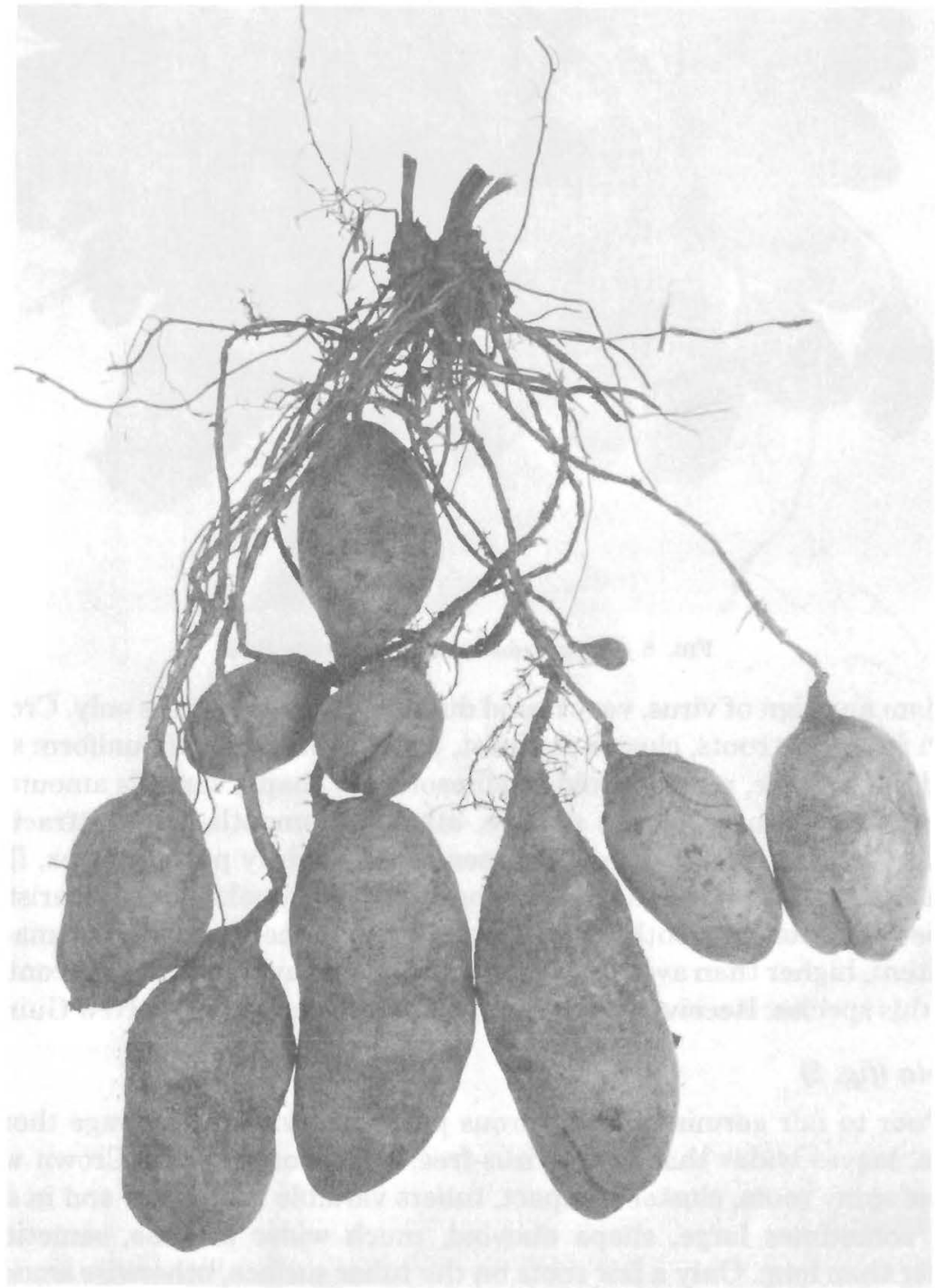

FIG. 7.-Tubers of variety Kombi. 


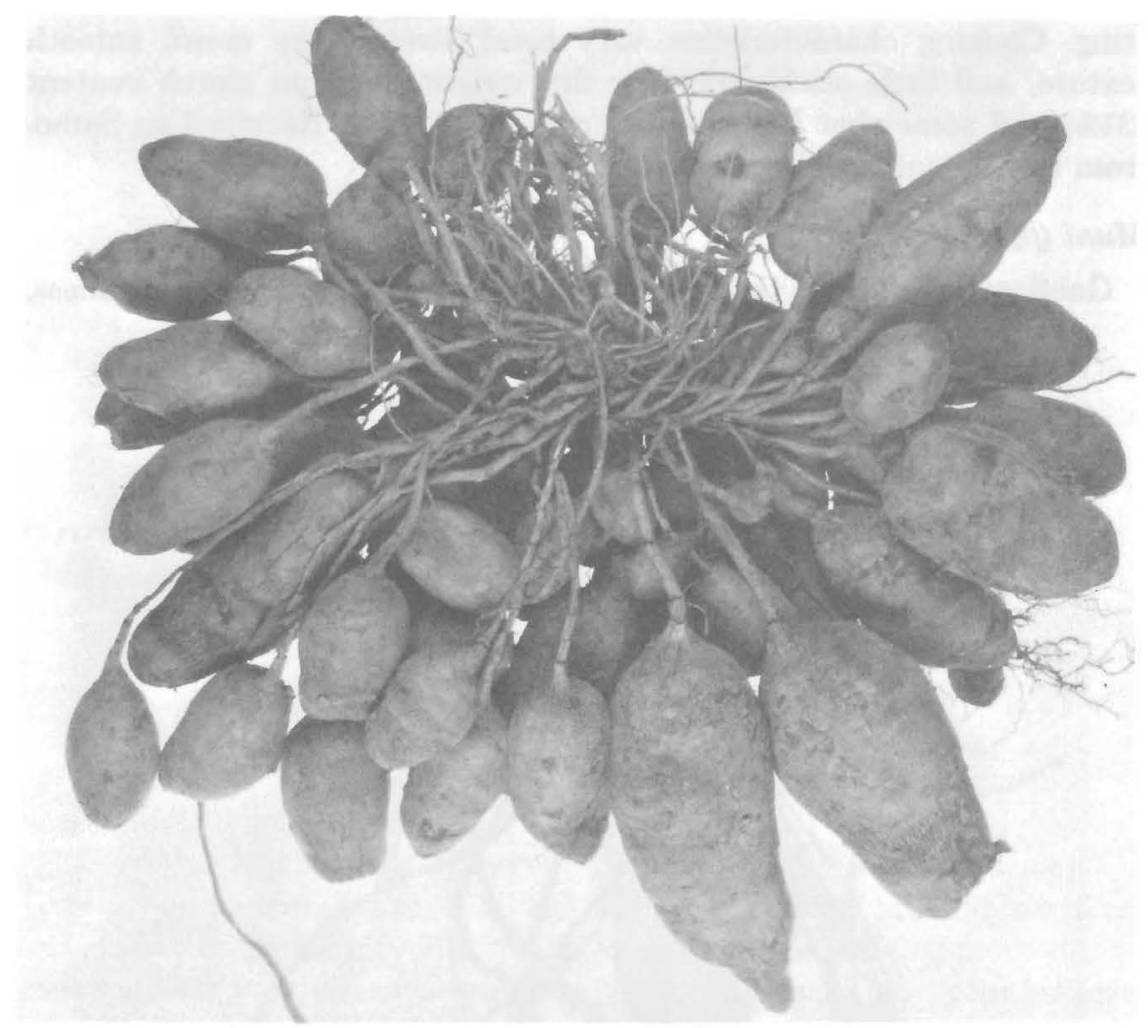

FIG. 8.-Large tuber cluster of variety Seti.

seldom any sign of virus, very round dull leaves, male flowers only. Crown with few spiny roots, cluster compact, many tubers of fairly uniform size, medium to large, mostly ovoid or ellipsoidal in shape, variable amount of fibrous or thorny roots on surface, otherwise smooth, fairly attractive, epidermis thin, yields high and dependable. Slightly purple cortex, flesh creamy white, uniform, does not sting. Very good cooking characteristics: sweet and moist, smooth texture, not sticky. Somewhat high dry matter content, higher than average starch content, and average amylose content for this species. Received from Keravat, New Britain, Papua New Guinea.

\section{Viola (fig. 6)}

Poor to fair germination, vigorous pubescent vines of average thorniness, leaves wider than long, virus-free, male flowers only. Crown with some spiny roots, cluster compact, tubers variable in number and in size, but sometimes large, shape obovoid, much wider at base, sometimes wider than long. Only a few roots on the tuber surface, otherwise smooth, epidermis tough, yields medium to high. Cortex thick and deep purple, 
flesh a mottled purple, tendency to oxidize after cutting, may sting. Cooking characteristics fair; acceptability reduced by anthocyanin, very sweet and moist, with smooth texture, very sticky, somewhat fibrous. High dry matter content, medium starch content, and high amylose content. Received from Keravat, New Britain, Papua New Guinea.

\section{Kombi (fig. 7)}

Excellent germination, very vigorous vines somewhat darkened by anthocyanin, more thorny than average, leaves wider than long, seldom any sign of virus. Crown with many spiny roots, clusters somewhat compact, variable in size. Tuber size variable, ovoid, twice as long as wide, surface often covered with a fair number of fibrous roots, otherwise smooth, epidermis thin, yields medium to high. Flesh uniformly clear white, does not sting. Excellent cooking characteristics; sweet and moist, crisp texture, somewhat sticky. Average dry weight, but lower than average starch content, lower amylose content. Received as Kombikum from Madang District, Papua New Guinea.

\section{Seti (fig. 8)}

Fair germination, average vigor and thorniness, very round, rugose leaves, slight virus symptoms sometimes seen (may account for occasional poor yields). Crown almost free of spines, clusters very compact, large numbers of tubers, small to medium in size, ellipsoidal in shape, but pressed into odd shapes by other tubers. Surface almost free of roots, very smooth, epidermis thin, yields low to high. Flesh very white, may sting slightly. Cooking characteristics better than average, not sweet but moist, slightly coarse texture, very sticky. Average dry weight, lower than average starch content, low amylose content. Received from Bali, Indonesia.

In addition to the varietal descriptions, the details of the evaluation of the six cultivars are given in table 2 . Using table 1 and table 2 it is possible to obtain the measurements of the characteristics observed or the ratings relative to the entire collection.

YIELDS AND FACTORS LIMITING YIELDS

$D$. esculenta introductions were found to be reliable with respect to vigor and tuber production. However, poor yields were often found associated with nematodes, on light soils, and with flooding on heavy soils. The plantings also suffered from excessive drought. Problems which affect other yam species, virus symptoms, leaf spot diseases, and insect attack, were not of importance in the case of $D$. esculenta.

Given reasonable care, long rainy seasons, supports on which to climb, and avoidance of flooding, all selections should be able to produce 25 or 
TABLE 2.-Evaluation of the 6 selected cultivars for 52 characteristics ${ }^{1}$

\begin{tabular}{|c|c|c|c|c|c|c|}
\hline Characteristic & Beti & Doli & Muni & Viola & Kombi & Seti \\
\hline 1 & 3 & 3 & 4 & 3 & 4 & 3 \\
\hline 2 & 4 & 3 & 3 & 4 & 4 & 3 \\
\hline 3 & 3 & 3 & 4 & 1 & 3 & 3 \\
\hline 4 & 3 & 3 & 3 & 3 & 4 & 3 \\
\hline 5 & 82 & 76 & 78 & 80 & 78 & 85 \\
\hline 6 & 116 & 118 & 123 & 124 & 130 & 127 \\
\hline 7 & 3 & 2 & 3 & 2 & 2 & 2 \\
\hline 8 & 3 & 5 & 5 & 3 & 3 & 5 \\
\hline 9 & 3 & 1 & 2 & 3 & 3 & 2 \\
\hline 10 & 3 & 1 & 2 & 3 & 3 & 4 \\
\hline 11 & 4 & 4 & 3 & 3 & 3 & 3 \\
\hline 12 & 2 & 3 & 1 & 2 & 2 & 2 \\
\hline 13 & 0 & 0 & 0 & 0 & 0 & 0 \\
\hline 14 & 4 & 5 & 1 & 3 & 0 & 0 \\
\hline 15 & 0 & 0 & 0 & 0 & 0 & 0 \\
\hline 16 & 0 & 0 & 1 & 0 & 0 & 0 \\
\hline 17 & - & - & 2 & - & - & - \\
\hline 18 & 5 & 10 & 11 & 8 & 11 & 10 \\
\hline 19 & 0 & 0 & 0 & 0 & 0 & 0 \\
\hline 20 & 0 & 0 & 0 & 0 & 0 & 0 \\
\hline 21 & 2 & 2 & 2 & 1 & 2 & 2 \\
\hline 22 & 19 & 13 & 13 & 12 & 19 & 10 \\
\hline 23 & 6.5 & 7.5 & 5.5 & 8 & 7 & 4 \\
\hline 24 & .34 & .58 & .42 & .67 & .37 & .40 \\
\hline 25 & 2 & 2 & 3 & 1 & 2 & 1 \\
\hline 26 & 2 & 2 & 2 & 3 & 2 & 1 \\
\hline 27 & 0 & 0 & 2 & 1 & 3 & 3 \\
\hline 28 & 1 & 0 & 3 & 3 & 2 & 0 \\
\hline 29 & 3 & 3 & 3 & 2 & 3 & 3 \\
\hline 30 & 0 & 1 & 1 & 2 & 1 & 1 \\
\hline 31 & 3 & 3 & 3 & 3 & 2 & 3 \\
\hline 32 & 0 & 0 & 0 & 0 & 0 & 0 \\
\hline 33 & 5 & 4 & 4 & 3 & 4 & 5 \\
\hline 34 & 1 & 1 & 1 & 1 & 2 & 1 \\
\hline 35 & 0 & 0 & 0 & 1 & 0 & 1 \\
\hline 36 & 1 & 1 & 1 & 2 & 2 & 3 \\
\hline 37 & 10 & 12 & 15 & 10 & 10 & 10 \\
\hline 38 & 1 & 1 & 1 & 3 & 1 & 1 \\
\hline 39 & 3 & 3 & 3 & 1 & 3 & 3 \\
\hline 40 & 1 & 1 & 1 & 5 & 1 & 1 \\
\hline 41 & 1 & 1 & 1 & 3 & 1 & 2 \\
\hline 42 & 2 & 1 & 1 & 3 & 2 & 3 \\
\hline 43 & 1 & 1 & 1 & 1 & 1 & 2 \\
\hline 44 & 3 & 3 & 3 & 3 & 3 & 3 \\
\hline 45 & 2 & 2 & 2 & 2 & 3 & 1 \\
\hline 46 & 2 & 3 & 2 & 3 & 3 & 3 \\
\hline 47 & 0 & 0 & 0 & 0 & 0 & 0 \\
\hline 48 & 1 & 1 & 1 & 2 & 2 & 1 \\
\hline 49 & 3 & 3 & 3 & 2 & 3 & 3 \\
\hline 50 & 36 & 27 & 33 & 33 & 31 & 30 \\
\hline 51 & 21 & 21 & 23 & 21 & 19 & 19 \\
\hline 52 & 11 & 14 & 16 & 20 & 12 & 12 \\
\hline
\end{tabular}

${ }^{1}$ Refer to table 1. 
TABLE 3.-Yields of Dioscorea esculenta selections over 3 years

\begin{tabular}{|c|c|c|c|c|c|c|c|}
\hline \multirow{3}{*}{$\begin{array}{l}\text { Cultivar } \\
\text { number }\end{array}$} & \multirow{3}{*}{ Name } & \multicolumn{6}{|c|}{ Yields } \\
\hline & & \multicolumn{3}{|c|}{$\mathrm{Kg}$ per plant } & \multicolumn{3}{|c|}{ Tons per hectare } \\
\hline & & 1974 & 1975 & 1976 & 1974 & 1975 & 1976 \\
\hline 18 & Beti & 1.02 & 1.3 & 2.34 & 11.1 & 14.5 & 26.0 \\
\hline 20 & Doli & 2.35 & 1.7 & 1.93 & 26.2 & 18.9 & 21.5 \\
\hline 32 & Muni & 2.43 & 2.4 & 2.48 & 27.0 & 26.7 & 27.6 \\
\hline 33 & Viola & 2.90 & 1.8 & 1.67 & 32.3 & 20.0 & 18.6 \\
\hline 97 & Kombi & 2.75 & 2.0 & 1.86 & 30.6 & 22.2 & 20.6 \\
\hline 273 & Seti & 2.90 & 1.3 & 1.34 & 32.3 & 14.5 & 14.9 \\
\hline
\end{tabular}

more metric tons per hectare of tubers in the hot, humid tropics (table 3). Over a 3-year period the highest yield per hectare was 48 tons when a small part of the collection was grown on a particular friable loam soil.

\section{DISCUSSION}

Because of its poor distribution throughout the tropics, $D$. esculenta has not had an opportunity to demonstrate its potential value except in a few isolated areas. The newly selected varieties, however, apparently produce tubers as useful and appealing as those of other species (D. alata and $D$. rotundata). The yields obtained are quite acceptable, and the crop appears to be fairly reliable. All varieties were disease and insectresistant in our trials. Thus, $D$. esculenta merits a trial in Puerto Rico and in other parts of the tropics. To expedite such trials tubers of the selections are being distributed to interested persons.

\section{RESUMEN}

Ochenta y cinco variedades de Dioscorea esculenta se evaluaron con respecto a 54 características morfológicas, fisiológicas, agronómicas y culinarias. Como resultado de la evaluación, seis variedades superiores se seleccionaron y se describieron. Son de alto rendimiento, resistentes a enfermedades e insectos. Demostraron ser excelentes en cuanto a la forma de prepararlas en la cocina y por su sabor. Estas variedades demuestran ser de utilidad en Puerto Rico y en otras partes del Caribe, especialmente como sustituto de la papa importada. 